\title{
Utilization of Mangrove Forest Plant: Nipa Palm (Nypa fruticans Wurmb.)
}

\author{
Md. Farid Hossain ${ }^{1}$, Md. Anwarul Islam² \\ ${ }^{1}$ School of Agriculture and Rural Development, Bangladesh Open University, Gazipur, Bangladesh \\ ${ }^{2}$ School of Education, Bangladesh Open University, Gazipur, Bangladesh \\ Email address: \\ faridhossain04@yahoo.com (Md. F. Hossain), anwarul2003islam@yahoo.com (Md. A. Islam)
}

\section{To cite this article:}

Md. Farid Hossain, Md. Anwarul Islam. Utilization of Mangrove Forest Plant: Nipa Palm (Nypa fruticans Wurmb.). American Journal of Agriculture and Forestry. Vol. 3, No. 4, 2015, pp. 156-160. doi: 10.11648/j.ajaf.20150304.16

\begin{abstract}
This review paper discusses the production, uses and importance of Nipa palm (Nypa fruticans Wurmb., Arecaceae). It is a mangrove palm that grows well in 'Sundarbans' mangrove forest of Bangladesh. Nipa palm is locally called 'Golpata' used for multipurpose such as roof thatching, partitioning, foods, medicinal purposes and as a source of fuel wood. The sugary sap from the inflorescence stalk is used as a source of treacle (molasses), amorphous sugar, vinegar and alcohol. Newly developed shoots are to be used as a vermicide. Ash from Nipa palm is used as an analgesic against tooth pain and headache. Dry leaves, petiole, stem wood, fruit residues etc. are used as fuel. In fishing, rhizomes of Nipa palm are extensively used, facilitating the fishing net to float over the water surface. This palm helps stabilizing soils, protecting against erosion, reducing the forces of cyclones and high sea waves in the coastal zones. The demand of Nipa palm products is increasing day by day in the different countries of the world including Bangladesh.
\end{abstract}

Keywords: Nipa Palm, Production, Uses, Importance, Mangrove Forest, Bangladesh

\section{Introduction}

Nipa palm (Nypa fruticans Wurmb., Arecaceae) is an important component of the East Asian mangrove vegetation. It is one of the oldest living palms [1, 2]. In Bangladesh, the natural distribution of Nipa palm is restricted to the 'Sundarbans', the largest single continuous tract of mangrove forest in the world [3, 4]. It grows along coastlines and estuarine habitats in the Indian and Pacific Ocean. It is a stem-less palm with tall erect fronds and underground rhizomatous stem [5] possessing an extensive root system, well suited to resist swift running water [6]. This familiar palm, growing naturally in the coastal areas and the demand of products is increasing day by day in Bangladesh [7]. Total nipa palm (Golpata) production was 320016 mounds in reserve forest of Bangladesh in 2011-2012 [8]. It is used mainly for housing, food, fuel, fence-making, medicine, cigarette wrapping, molasses, wine, fishing etc. The kernels of immature fruits are used as food. Another important product 'Gur' (molasses) to be sold, which generally followed a short marketing chain; this product is sold directly to the end-users in villages or in local markets [7]. The role of nipa palm is invaluable for both the rural and urban livelihood economies of Bangladesh. People living around the 'Sundarbans' depend on Nipa palm and about $80 \%$ of houses in the area are made of Nipa palm [9]. Its sap may be a prospective source for production of sugar, vinegar and alcohol. Nipa palm serves as the first line of defense against the impacts of tsunami, hurricanes, and cyclones that reduce the damages in the coastal zones. The paper is an overview of nipa palm considering origin, distribution, habitat, uses and importance aspect. The information out lined in this article have been collected from different national and international agricultural, food and forest journals, different reports of FAO and visited of useful websites etc.

\section{Origin and Distribution of Nipa Palm}

It was postulated that this species had an original distribution from Asia extending to Europe, Africa, and America. Its current range is now confined within the tropical Indo-West Pacific region, from Sri Lanka through Asia to Northern Australia and the Western Pacific islands, suggesting changing climatic conditions and/or the loss of 
versatile genotypes that can tolerate wider environmental conditions $[10,11]$.

\section{Nipa Palm in Mangrove Forest}

'Mangroves' is an ecological term referring to a taxonomically diverse assemblage of trees and shrubs that form the dominant plant communities in tidal and saline wetlands along sheltered tropical and subtropical coasts. Economically, mangroves are a great source of timber, poles, thatch and fuel and the bark is used for tanning materials; some species have food or medicinal value [12]. Nypa fruticans is a species best adapted to grow in mangrove coastal areas with moderate only salt load, and circumscribing quite well the actual areas of occurrence of this palm in the gradient from seawater habitats to inland sites [13]. It is a mangrove palm that grows well in calm estuaries and coastal zones. The species can prevail in a simple channel or complex tributaries, bays, tidal flats and creeks, as long as there is a tide and a freshwater outflow action [14]. Nipa palm usually thrives well in the sediments deposited by an accreting process by the sea, creating a clayish type of soil, with brackish water that promotes an anaerobic system [15]. It grows in soft mud, usually where the water is calmer, but where there is regular inflow of freshwater and nutritious silt. They can be found inland, as far as the tide can deposit the Palm's floating seeds. It can tolerate infrequent inundation, so long as the soil does not dry out for too long. Its horizontal creeping stem stabilizes river banks preventing soil erosion. New fronds emerge quickly after damage and so quickly protect the land after storms and also continuously produce useful products for the locals [16].

\section{The Coastal Zone of Bangladesh}

The coastal zone covers 19 out of 64 districts/zilas facing or in proximity to the Bay of Bengal, encompassing 153 upazilas [17]. The zone constitutes 32 percent of the area and 28 percent of the population of Bangladesh [18].

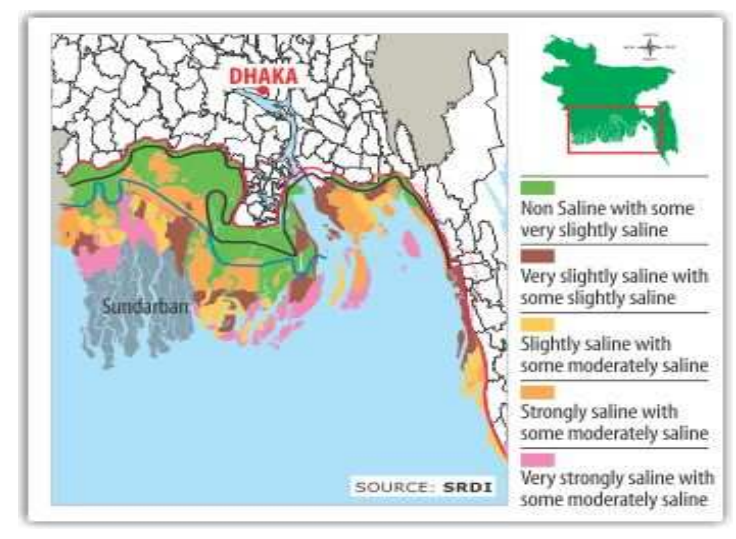

Figure 1. The coastal zone of Bangladesh [19].

In 12 of these districts, 51 upazilas face a combination of cyclone risk, salinity and tidal water movement above critical levels and are designated as "exposed coast" (Figure 1, green areas). The coastal zone covers an area from the shore of 37 to 195 kilometers, whereas the exposed coast is limited to a distance of 37 to 57 kilometers [20].

\section{Morphology of Nipa Palm}

Nipa is a monocious and pleonanthic palm; it also exhibits viviparous germination [21] as in many other mangrove species. The leaves of nipa palm can grow up to $10 \mathrm{~m}$, and arise from a dichotomously branched underground rhizome that grows to about $50 \mathrm{~cm}$ in length [1,22]. The species lacks a visible upright trunk, and the leaves appear from the ground. The younger leaves appear from the middle of the crown and push the older leaves aside before they dry and fade away, leaving bulbous leaf bases or scars behind. The diameter of the cluster could be up to $75 \mathrm{~cm}$ and a single leaf may attain a height of $8 \mathrm{~m}$. The mature crown may contain 6 to 8 living leaves and 12 to 15 bulbous leaf bases at a time [15].

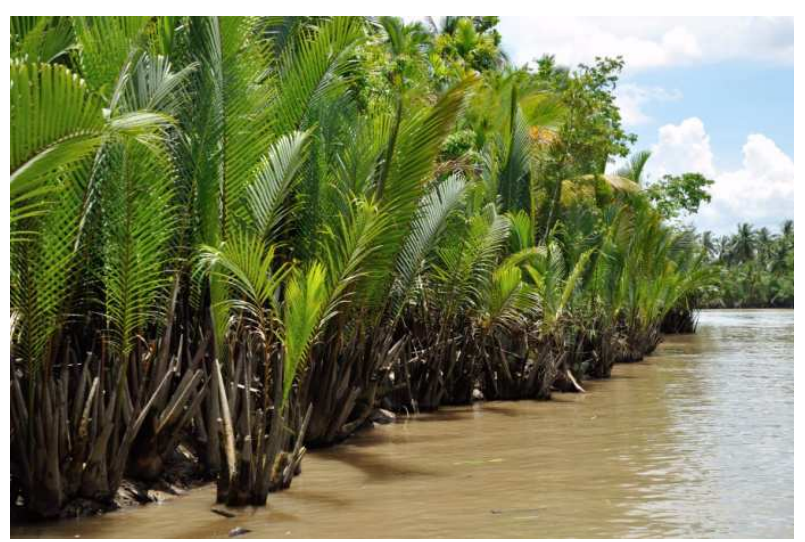

Figure 2. Nipa palm plant [23].

The collection of leaves normally started from the 6-7 year old plants within the plantation. A slanting cut, maintaining a $45^{\circ}$ angle is used. The cutting height above the ground depends on the planting density. If the density is high, cutting is undertaken at 7 or $8 \mathrm{~cm}$ above the ground and in case of low density, at 5 or $6 \mathrm{~cm}$. The season of harvesting was January to February as new shoot development begins in March [7].

\section{Uses of Nipa Palm}

Nipa palm is utilized by humans for several purposes, such as roof thatching, wall partitioning, making of sun hats and mats, foods like edible young seed, aromatic tea from leaf blade, sugar from xylem sap, medicinal purposes, bio-ethanol production, and remediation of heavy metal from polluted sites [24-26]. Newly developed shoots are to be used as a vermicide. Ash from Nipa palm is used as an analgesic against tooth pain and headache. Dry leaves, petiole, stem wood, fruit residues etc. are used as fuel. In fishing rhizomes of Nipa palm are extensively used, facilitating the fishing net to float over the water surface. Farmers also report that Nipa palm in the river or sea attracts deep-water fish. The juice is 
used for making molasses and alcohol [7]. The tapping of the palm for beverages such as wine or toddy and identify this as an ancient and traditional practice in Pan-Pacific and South and Southeast Asian countries [12, 27]. Nipa palm has a great potential for commercial use in housing and medicine in Bangladesh [28]. It is using for housing and other important purposes [29]. The long, pinnate leaves (fronds) provide material for thatching houses. In the Philippines, Malaysia, Indonesia and Thailand the fabrication of thatching panels, called locally 'shingles', 'pawid' or 'atap', is a significant local source of income. Leaflets and midribs are used for manufacturing of brooms, baskets, mats and sunhats. The white endosperm of immature seeds is sweet and jelly-like and is consumed as a snack. The cuticle of young, unfurled leaves has locally been used as cigarette wrapping. Various parts of nipa palm are a source of traditional medicines such as juice from young shoots is used against herpes, ash of burned nipa palm material against toothache and headaches. Nipa palm material also use for salt extraction. The use of the hard shell (mesocarp) in the making of buttons, necklaces and other fashion apparels is successful in Nigeria. Nipa fronds are commonly used as sails by local fishermen [26]. The leaves have traditionally been used for roof thatching and parts are used for making umbrellas, raincoats, hats, mats, brooms, baskets, cigarette wrappers, ropes, and as a source of fuel wood. The sugary sap from the inflorescence stalk is used to make vinegar, and like those of other palms such as the coconut, its sap is also used to make a popular alcoholic beverage better known as "toddy" in Malaysia, India, and Bangladesh. The gelatinous endosperm from the young seeds is edible and can be eaten raw or preserved in 'heavy syrup' while the hardened ones from the ripened fruits are used as vegetable ivory and buttons. Parts of the palm like young shoots, decayed wood, and the burned roots and leaves are also used as traditional medicinal remedies for the treatment of headaches, toothaches, and herpes [30]. Before the inflorescence blooms, it is tapped to collect a sweet sap. Young Nipa Palm shoots can be eaten. The petals of the flower can be brewed to make an aromatic tea. The immature fruits are white translucent and hard jelly-like. Called attap chee, they are a common ingredient in local desserts [16]. In South-East Asia, there is a long tradition of using palm sap obtained by tapping the inflorescence stalks (peduncle) as a source of treacle (molasses), amorphous sugar ('gula malacca'), alcohol or vinegar. The slightly fermented sap called 'toddy' ('nera' in Indonesia and Malaysia; 'tuba' in the Philippines) is sold and consumed as local beer. In Papua New Guinea, there is no tradition of using the sap [26].

\section{Molasses (Gur) Production from Nipa Palm Sap}

Sap is a product of photosynthesis; frond (leaf) biomass is likely related to sap production. Nypa fruticans frond biomass is the crucial factor for sap/sugar production. The growth properties of the nipa fruit stalk, as well as the water status, were shown to affect sap production [31].

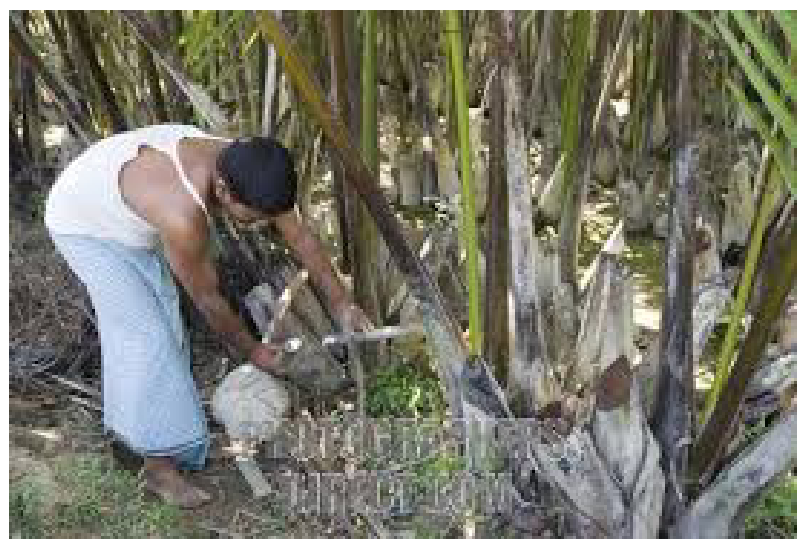

Figure 3. Sap collection from Nipa palm plant [32].

Nipa palm is also much valued for the sweet sap tapped from the stalk of the inflorescence. It was reported that tapping normally commences from the Nipa palm shoots after four years and continues up to 15 years or more. The shoots of 9-12 year old stems are reported to be the highest yielding, providing up to $1500-1900 \mathrm{ml}$ of sap per stem per season. The stems of 15 years or more were reported to yield a reduced sap production. The farmers also reported that palms from canals, ditches or riversides gave the highest amount of sap. Tapping began from the first week of December when the fruit begins to mature and turns tan and this was continued up to the next mid-March. The stalk of inflorescence was then pulled down and every morning and evening, a thin slice of stalk was removed and sap collected in a container. It was also reported that $1 \mathrm{~kg}$ molasses was produced from 7-8 liters of sap. Most of the farmers were reluctant to tap the stems because of the decline in the quality of leaf production. However, it was observed that $10 \%$ of the landless farmers tapped the stems for wine [7].

\section{Factors Affecting Growth and Sap of Nipa Palm}

Nipa palm is a tropical plant. The average minimum temperature in its growing areas is $20^{\circ} \mathrm{C}$ and the maximum $32-35^{\circ} \mathrm{C}$. Its optimum climate is sub-humid to humid with more than $100 \mathrm{~mm}$ rainfall per month throughout the year. Nipa palm thrives only in a brackish water environment. It is rarely seen directly on the seashore. Optimum conditions are when the base and the rhizome of the palm are regularly inundated by brackish water. For this reason, nipa palm occupies estuarine tidal floodplains of rivers. The optimum salt concentration is 1-9 per mil. Nipa palm swamp soils are muddy and rich in alluvial silt, clay and humus; they have a high content of various inorganic salts, calcium, and sulphides of iron and manganese, contributing to the typical odour and dark color. The $\mathrm{pH}$ is around 5; oxygen content is low with the exception of the topmost layers. Typically, nipa palm forms pure stands, but in some areas it grows mixed with other mangrove trees [26]. In general, mangrove forests 
are composed of salt-tolerant plant species that have special adaptations to $\mathrm{NaCl}$ stress, including salt-filtering roots and salt-excreting glands on leaves [33]. Nipa palm is distributed at mangrove coasts preferably at the hypo saline end of the sea water-inland gradient and extends more upstream than the dicot mangrove trees at the banks of river mouths [10]. In salt-affected glycophytic palm species, $\mathrm{Na}^{+}$is accumulated in the cells, and plants show toxicity symptoms such as chlorophyll degradation, diminished chlorophyll fluorescence, reduced net photosynthesis, and overall growth inhibition [34, 35]. Free proline is an osmolyte that plays a role in osmoregulatory defense mechanisms in higher plants exposed to salt or drought stress. Free proline accumulation in saltstressed seedlings of glycophytic palm species has already been investigated $[36,33]$. The overall growth performance and physiology of 6-month-old seedlings of Nipa palm was unaffected by mild salt stress $\left(8.9-16.6 \mathrm{dS} \mathrm{m} \mathrm{m}^{-1}\right)$, whereas seedlings grown under severe salt stress $\left(\mathrm{EC}=57.2 \mathrm{dS} \mathrm{m}^{-1}\right)$ had lower chlorophyll content and fluorescence, reduced net photosynthesis and transpiration, which resulted in reduced growth of the plants. $\mathrm{Na}^{+}$contents in leaf, petiole, and root tissues increased considerably under salt stress, depending upon the $\mathrm{NaCl}$ levels in the soil solution. Under salt-stress $\mathrm{K}^{+}$ content declined, whereas $\mathrm{Ca}^{2+}$ content increased somewhat, in parallel to $\mathrm{Na}^{+}$. Free proline accumulated in plants growing under high salt stress $\left(\mathrm{EC}=57.2 \mathrm{dS} \mathrm{m}^{-1}\right)$. In contrast, soluble sugars were enriched under inter-mediate levels of salt stress $\left(\mathrm{EC}=16.6 \mathrm{dS} \mathrm{m}^{-1}\right)$. Nypa fruticans is a species best adapted to grow in mangrove coastal areas with moderate only salt load, and circumscribing quite well the actual areas of occurrence of this palm in the gradient from seawater habitats to inland sites [13]. Sap production would be controlled by the nipa growth and the amount of $\mathrm{Na}^{+}$in soil. Both the frond biomass surrounding fruit stalk and above-ground biomass are related to sap production. Frond biomass explained the variance of sap production by $48 \%$ and above-ground biomass explained by $57 \%$. Sap production will increase by an increase of soil organic matter content and when the influence of brackish water decreases. Sap could be produced more when the farm is managed such that the influence of brackish water is reduced [31]. From recent studies of mangrove mortality at several locations including Guiana, Gambia, Côte d'Ivoire, Kenya, India and Bangladesh, it appears that these coastal ecosystems are so specialized that any minor variation in their hydrological or tidal regimes causes noticeable mortality. Each species of mangrove (but particularly those belonging to the genera Rhizophora, Bruguiera, Sonneratia, Heritiera and Nypa) occurs in ecological conditions that approach its limit of tolerance with regard to salinity of the water and soil, as well as the inundation regime [37]. Sap sugar concentration of Nypa fruticans vary due to collection time. Maximum sugar content $(10 \%)$ was in November 1996 whereas, minimum sugar content (8\%) was found in April 1997 under an experiment at the Chakaria Sundarbans area of Bangladesh [38].

\section{Conclusion}

Nipa Palm is growing naturally in the coastal areas with a brackish water environment. It sap may be a prospective source for production of sugar, vinegar and alcohol. The role of Nipa palm is important in the coastal areas people's livelihood of Bangladesh. Multipurpose uses and export potentiality of Nipa palm products can increase the worldwide demand day by day.

\section{Acknowledgements}

The author thanks to Dr. N. M. Talukder, former Professor, Department of Agricultural Chemistry, Bangladesh Agricultural University, Mymensingh, Bangladesh for his valuable suggestions and cordial cooperation.

\section{References}

[1] Badve, R. M. and Sakurkar, C.V. 2003. On the disappearance of palm genus Nypa from the west coast with its present status in the Indian subcontinent. Curr. Sci. 85:1407-1409.

[2] Gee, C.T. 1989. On the fossil occurrences of the mangrove palm Nypa. Paper presented at the symposium; Paleofloristic and paleoclimatic changes in the Cretaceous and Tertiary. Prague.

[3] Chaudhuri, A.B. and Naithani, H.B.1985. A comprehensive Survey of Tropical Mangrove Forests of Sundarbans and Andaman's. Part I. International Book Distributors, Dehra Dun, India. $41 \mathrm{pp}$.

[4] Akhtaruzzaman, A.F.M. 2000. Mangrove Forestry Research in Bangladesh. In: Asia-Pacific Cooperation on Research for Conservation of Mangroves, Proceedings of an International Workshop, 26-30 March, 2000, Okinawa, Japan. pp. 139-146.

[5] Shahidullah, M. 2001. Nursery and Plantation Techniques of Golpata (Nypa fruticans). In: Siddiqui, N.A. and M.W. Baksha (eds.), Proceedings of the National Workshop on Mangrove Research and Development at Bangladesh Forest Research Institute, Chittagong, Bangladesh 15-16 May, 2001.pp.33-38.

[6] Percival, M. and Womersley, J.S. 1975. Floristics and Ecology of the Mangrove Vegetation of Papua New Guinea. Botany Bulletin No. 8, Department of Forests, Papua New Guinea. 94pp.

[7] Miah, M.D.; Ahmed, R. and Islam, S.J. 2003. Indigenous Management Practices of Golpata (Nypa fruticans) in Local Plantations in Southern Bangladesh. PALMS. 47(4):185-190.

[8] BBS. 2013. Statistical Year Pocket Book. Bangladesh Bureau of Statistics. Ministry of Planning. Peoples Republic of Bangladesh.

[9] Faizuddin, M.; Rahman, M.M.; Shahidullah, M.; Helalsiddiqui, A.S.M.; Hasnin, M. and Rashid, M.H. 2000. Golpata (Nypa fruticans) important forests produce of the Sundarbans. Mangrove silviculture division, Bangladesh Forest Research Institute (BFRI), Khulna, Bangladesh.

[10] Duke, N. 2006. Australia's Mangroves. The Authoritative Guide to Australia's Mangrove Plants. University of Queensland, Queensland. 200 pp. 
[11] Dransfield, J.; Uhl, N.W.; Asmussen,C.B.; Baker,W.J.; Harley, M.M. and Lewis,C.E. 2008. Genera Palmarum: The Evolution and Classification of Palms. Royal Botanic Gardens, Kew. 732 pp.

[12] Hamilton, L. S. and Murphy, D.H.1988. Use and management of Nipa Palm (Nypa fruticans, Arecaceae): A review. Economic Botany. 42(2): 206-213.

[13] Theerawitaya, C.; Samphumphaung,T.; Cha-um, S.; Nana Yamada, N. and Takabe, T. 2014. Responses of Nipa palm (Nypa fruticans) seedlings, a mangrove species, to salt stress in pot culture. Flora - Morphology, Distribution and Functional Ecology of Plants 209 (10):597-603.

[14] Fong, F.W. 1982. Nypa swamps in Peninsular Malaysia. Proceedings of the First International Wetlands Conference. Wetlands: Ecol. Manage., pp. 31-38.

[15] Rozainah, M. Z and Aslezaeim, N. 2010. A demographic study of a mangrove palm, Nypa fruticans. Scientific Research and Essays.5 (24):3896-3902.

[16] http://www.naturia.per.sg/buloh/plants/palm_nipah.htm

[17] MoWR. 2006. Coastal Development Strategy. Ministry of Water Resources. Government of the People's Republic of Bangladesh.

[18] Islam, M.R. (Ed.). 2004. Where land meets the sea: a profile of the coastal zone of Bangladesh. Dhaka, the University Press Limited. 317 pp.

[19] http://www.thedailystar.net/beta2/wpcontent/uploads/2013/07/fr0151.jpg

[20] Islam, M.R.; Ahmad, M.; Huq, H. and Osman, M.S. 2006. State of the coast 2006. Dhaka, Program Development Office for Integrated Coastal Zone Management Plan Project, Water Resources Planning Organization.

[21] Tomlinson, P. S. 1986. The Botany of Mangroves. Cambridge University Press, New York. 413 pp.

[22] Teo, S.; Ang, W.F.; Lok, A.F.S.L.; Kurukulasuriya, B.R. and Tan, H.T.W. 2010. The status and distribution of the nipah, Nypa fruticans Wurmb (Arecaceae), in Singapore. Nat. Singapore. 3: 45-52.

[23] http://www.vietnampictures.com/tour_to_vietnam/vietnam_photos_big/DSC_292 9.jpg

[24] Okugbo, O.T.; Usunobun, U.; Esan, A.; Adegbegi, J.A., Oyedeji, J.O. and Okiemien, C.O. 2012. A review of Nipa palm as a renewable energy source in Nigeria. Res. J. Appl. Sci. Eng. Technol. 4, 2367-2371.

[25] Tsuji, K.; Ghazalli, M.N.F.; Ariffin, Z.; Nordin, M.S. Khaidizar, M.I.; Dulloo, M.E. and Sebas-tian, L.S. 2011. Biological and ethnobotanical characteristics of nipa palm
(Nypa fruticans Wurmb.): a review. Sians Malaysia 40: 14071412.

[26] Wankasi, D.; Horsfall Jr., M. and Spiff, A.I., 2006. Sorption kinetics of $\mathrm{Pb} 2+$ and $\mathrm{Cu} 2+$ ions from aqueous solution by Nipah palm (Nypa fruticans Wurmb.) Shoot biomass. Elect. J. Biotechnol. 9:587-592(www.cabi.org/isc/.../36772).

[27] FAO. 1995. Integrated Resource Development of the Sunderbans Reserved Forest, Bangladesh. Draft final report. FAO: DP/BGD/84/056.

[28] Shiva, M.P. 1994. Report on Mangrove Non-wood Forest Products. FAO/UNDP project BGD/84/056, Khulna, Bangladesh. $147 \mathrm{pp}$.

[29] Killmann, W.; Wong,W.C. and Shaari, K.1989. Utilization of Palm stems and leaves: an annotated bibliography. Forest Research Institute, Kuala Lumpur, Malaysia.

[30] Burkill, I. H.1966. A Dictionary of the Economic Products of the Malay Peninsula. Volume II. Crown Agents for the Colonies, London. 2444 pp.

[31] Matsui, N.; Okimori,Y.;, Fumio Takahashi,F.; Matsumura, K. and Bamroongrugsa, N. 2014. Nipa (Nypa fruticans Wurmb) Sap Collection in Southern Thailand II. Biomass and Soil Properties. Environment and Natural Resources Research.4 (4).

[32] http://img1.photographersdirect.com/img/26650/wm/pd26504 43.jpg

[33] Ame, R.B.; Ame, E.C. and Ayson, J.P., 2011. Management of the Nypa mangrove as a mitigating measure against resource over-utilization in Pamplona. Cagayan. Kuroshio Sci. 5, 7785.

[34] Cha-um, S.; Takabe, T. and Kirdmanee, C. 2010. Ion contents, relative electrolyte leakage, proline accumulation, photosynthetic abilities and growth characters of oil palm seedlings in response to salt stress. Pak. J. Bot. 42, 2020-2191.

[35] Youssef, T. and Awad, M.A. 2008. Mechanisms of enhancing photosynthetic gas exchange in date palm seedlings (Phoenix dactyifera L.) under salinity stress bya 5 -aminolevunic acidbased fertilizer. J. Plant Growth Regul. 27, 1-9.

[36] Al-Khayri, J.M. 2002. Growth, proline accumulation, and ion content in sodium chloride-stressed callus of date palm. In Vitro Cell. Dev. Biol. Plant. 38:79-82.

[37] Blasco, F.; Saenger, P. and Janodet, E. 1996. 'Mangroves as indicators of coastal change', Catena. 27(3-4):167-178. (Available at http://dx.doi.org/10.1016/0341-8162 (96)00013$6)$.

[38] Das, S.C.; Akhter, S.; Wazihullah A.K.M. and Rahman, M.S. 2000. Yield of Vinegar, Alcohol and Sugar from the Sap of Nypa fruticans. Bangladesh J. Forest Sc. 29: 92-96. 